\title{
Paratonia enlightened : definition, diagnosis, course, riskfactors, and treatment
}

Citation for published version (APA):

Hobbelen, J. S. M. (2010). Paratonia enlightened : definition, diagnosis, course, riskfactors, and treatment. [Doctoral Thesis, Maastricht University]. Maastricht University. https://doi.org/10.26481/dis.20101214jh

Document status and date:

Published: 01/01/2010

DOI:

10.26481/dis.20101214jh

Document Version:

Publisher's PDF, also known as Version of record

\section{Please check the document version of this publication:}

- A submitted manuscript is the version of the article upon submission and before peer-review. There can be important differences between the submitted version and the official published version of record.

People interested in the research are advised to contact the author for the final version of the publication, or visit the DOI to the publisher's website.

- The final author version and the galley proof are versions of the publication after peer review.

- The final published version features the final layout of the paper including the volume, issue and page numbers.

Link to publication

\footnotetext{
General rights rights.

- You may freely distribute the URL identifying the publication in the public portal. please follow below link for the End User Agreement:

www.umlib.nl/taverne-license

Take down policy

If you believe that this document breaches copyright please contact us at:

repository@maastrichtuniversity.nl

providing details and we will investigate your claim.
}

Copyright and moral rights for the publications made accessible in the public portal are retained by the authors and/or other copyright owners and it is a condition of accessing publications that users recognise and abide by the legal requirements associated with these

- Users may download and print one copy of any publication from the public portal for the purpose of private study or research.

- You may not further distribute the material or use it for any profit-making activity or commercial gain

If the publication is distributed under the terms of Article $25 \mathrm{fa}$ of the Dutch Copyright Act, indicated by the "Taverne" license above, 

ติ 
Chapter 1 gives an overview of the history behind this thesis. Paratonia is a distinctive muscletone disorder in late stage dementia that, although already noticed and described in 1910, never gained much scientific interest. Paratonia is noted to be of importance in the decline of the quality of life and results in an exponential increase of the carer's burden in the final stages of dementia. The prevalence of paratonia is estimated on $10 \%$ in the early stages towards $90 \%$ in the final stages of dementia. In the international literature exists a wide variety of descriptions and limited hypotheses about the origin of paratonia. Passive movement therapy (PMT) is one of the main interventions administered by physiotherapists in Dutch nursing homes to reduce the muscle tone and sustain the range of motion. Although carers claim that this therapy is beneficial physiotherapists have some doubts about the efficacy and this was the main reason to increase the insight into Paratonia. For this we formulated four aims; (1) The realization of a valid description of paratonia.

(2) To give the clinician a tool for diagnosing paratonia by which differentiation with other muscle tone disorders can be established.

(3) To point out factors that influence the development and severity of paratonia.

(4) To answer the question if PMT has any beneficial effect on the severity of paratonia in late stage dementia patients.

Chapter 2 describes a Pilot Randomized Clinical Trial investigating the effect of passive movement therapy in severe paratonia compared with good stabilizing cushions and a control group. This randomised clinical trial involved residents of the psychogeriatric unit of the 'De Weerde' nursing home in Eindhoven, the Netherlands. Participants were randomised over three groups: group 1 received three sessions of PMT per week, group 2 used supporting cushions, and group 3 acted as a control group. Nine treatment sessions were given, and subjects were evaluated before and after each session using a modified Ashworth scale for measuring severity of paratonia. All four limbs were assessed in four movement directions (flexion, extension, abduction, and adduction). After screening and proxy consent fifteen patients were included, five in each group. Supporting cushions were most beneficial for both arms after three weeks of treatment, and for flexion of both legs after one treatment session (not significant). Trend analyses showed that PMT appears to be beneficial after one treatment, which supports carers' claims of a positive effect. However, the long-term effects of PMT were questionable.

Chapter 3 describes a Delphi procedure to establish an international consensus definition. The Delphi procedure involved an anonymous and multi-stage approach presented as a questionnaire, with each stage building on the results of the previous one. Eight out of 17 identified and addressed experts agreed to participate. The questionnaire was divided into three categories: commonly used descriptions, influencing factors, and features that can 
differentiate between paratonia, parkinson's rigidity and spasticity. After four rounds the participants reached consensus on the importance of 4 short descriptions, 4 influencing factors and 2 differentiating elements which was compiled to one description of paratonia. Paratonia is a form of hypertonia with an involuntary variable resistance during passive movement. The nature of paratonia may change with progression of the dementing illness (e.g. Active assistance (also known as Mitgehen) is more common early in the course of degenerative dementias, whilst active resistance is more common later in the course of the disease). The degree of resistance varies depending on the speed of movement (e.g. Low resistance to slow movement and high resistance to fast movement). The degree of paratonia is proportional to the amount of force applied. Paratonia increases with progression of dementia. Furthermore, the resistance to passive movement is in any direction and there is no clasp-knife phenomenon.

Chapter 4 describes the transformation of the new consensus definition towards a feasible assessment instrument. For this we used a three-phase cross-sectional survey. In the first two phases, the Paratonia Assessment Instrument (PAI) was developed and validated. In the third phase, the inter- observer reliability and feasibility of the instrument was tested. Interobserver reliability between the two assessors resulted in an improvement of Cohen's $\mathrm{k}$ from 0.532 in the initial phase to 0.677 in the second phase. Two independent assessors validated this improvement in the third phase with Cohen's $\mathrm{k}$ ranging from 0.625 to 1.

The definite PAI is a construct of five criteria representing distinct elements of the clinical manifestation of paratonia. The presence of paratonia can be established by conducting passive movement of the shoulders, elbows and hips through flexion and extension while the patient is in a seated position. The five criteria that all need to be met in order to make the diagnosis of paratonia are: 1) there is an involuntary variable resistance,2) the degree of resistance varies depending on the speed of movement (e.g. a low resistance by slow movement and a high resistance by fast movement),3) the resistance to passive movement can be in any direction, 4) there is no clasp-knife phenomenon and 5) the resistance is felt in 2 movement directions in 1 limb or in 2 different limbs.

Chapter 5 describes a multi-centre longitudinal 1-year follow-up cohort study to investigate the prevalence, incidence and the risk factors of paratonia in dementia. Fit and mobile persons with dementia, scoring stage 6 or lower on the Global Deterioration Scale of Reisberg (GDS), were considered eligible for inclusion and were only included after written informed or proxy consent. They were enrolled from Dementia day-care centres of nursing homes and residential homes with dementia special care units (DCUs) in the regions Eindhoven, Helmond and Tilburg in the Netherlands. 
Participants were assessed with the Paratonia Assessment instrument (PAl) as our primary assessment instrument. The functional mobility was assessed with the Timed Up and GO (TUG)test, the quality of life with the Qualidem, the severity of dementia with the GDS of Reisberg, the cognitive function with the Mini Mental State Examination (MMSE) and the diagnosis of dementia, co-morbidities and the use of medication were obtained from the participants' medical dossier combined with the General Practitioners' (GP) files. The PAI was assessed every 3 months. All other variables were assessed at baseline and after 12 months. Baseline measures were assessed in 204 participants, 111 (54\%) female and 93 (46\%) male with a mean age of 79.8 years (56-97). 71 (34.8\%) were diagnosed with paratonia at baseline and 51 developed paratonia over one year. In the Vascular Dementia group the highest Hazard ratio (3.1) for developing paratonia in 1-year time was found and one of the highest prevalences at baseline (42\%).

Logistic regression analysis revealed that one unit lower on the MMSE $(\mathrm{OR}=.90)$ and Diabetes Mellitus ( $O R=10.7)$ were significantly related to the development of paratonia (Wald chi square $\mathrm{p}$-value <.01). We concluded that DM is a significant risk factor for the development of paratonia as well as probably vascular damage.

Chapter 6 describes the study protocol of a Multicentre Randomized Clinical Trial (RCT) to investigate the effect of passive movement therapy (PMT) on the severity of paratonia and on the improvement of daily care.

A RCT with a 4-week follow-up is proposed with dementia patients with moderate to severe paratonia. Patients are only included after proxy consent. With computerized and concealed block randomization (block size of 4) patients are included in one of two groups. The first group receives PMT, the second group receives usual care without PMT. In this chapter an extensive account is given on how PMT should be administered. The study protocol prescribes PMT by a physiotherapist three times a week for four weeks in a row. The main outcome measure is the Modified Ashworth scale to assess the severity of paratonia. To assess the improvement on daily care we introduced in this study protocol as secondary outcome measures the Clinical Global Impressions ( $\mathrm{CGI}$ ) and a modified version of the Patient Specific Complaints (PSC). Furthermore, to assess a decrease of pain during daily care as a possible side-effect of PMT the Pain Assessment Checklist for Seniors with Limited Ability to Communicate, Dutch version (PACSLAC-D), is proposed. Data collection will be at baseline shortly before the first treatment, after two weeks one day after to the $6^{\text {th }}$ treatment and after four weeks one day after the $12^{\text {th }}$ and final treatment. Sample size calculations are based on the analyses of the pilot study (chapter 2) and indicate a sample size of 69 patients per group. This chapter ends with a proposal for the statistical analyses. 
Chapter 7 describes the results of the multicentre Randomized Clinical Trial in 12 nursing homes across the Netherlands. A total of 102 patients participated and data of 101 participants were analysed. Data collection took place between April 2007 and April 2009. Of the participants $82.2 \%(n=83)$ were female. The mean age was 84 years (range $67-98$ years) and most of the participants $(65.3 \%, n=66)$ were in the most severe stage of dementia GDS 7 and 34.7\% ( $n=35)$ in GDS 6 stage. Sixty-three percent $(n=64)$ had Alzheimer dementia (AD), $18 \%(n=18)$ had vascular dementia $(\operatorname{VaD}), 11 \%(n=11)$ a combination of $A D$ and $\operatorname{VaD}, 4 \%(n=4)$ had a diagnosis of Lewy Body dementia and in $4 \%(n=4)$ of patients dementia was not otherwise specified.

The Ashworth score was analysed with mixed effects linear models on three levels, time level nested within patient level nested within institution.

This procedure was also used in the analysis of the PACSLAC-D and the PSC. To account for the dependency of the three subsequent questions about the carer's strain of the PSC these data have been fully cross-classified with time at first level.

In all analyses we accounted for the differences of the different types and stages of dementia, the baseline assessments and a natural time effect. In order to test if PMT has a different effect in the different nursing homes, the different types of dementia or stages of the disease, we entered these factors as interaction terms in the models. Finally the CGI has been analysed with cross-tabulation chi-square.

This study found that PMT does not decrease muscle tone but shows a trend towards worsening of joint and limb stiffness compared with controls. Although not statistically significant, we found it clinically very relevant because this therapy is meant to reduce the muscle tone. Furthermore, there is no indication that the carer's strain decreases as a consequence of PMT. PMT is therefore not recommended as an intervention in severe paratonia

Chapter 8, the general discussion, gives an overview of the main results of this thesis and the methodological strengths and limitations of the subsequent studies. Furthermore, it discusses the clinical implications of the main findings and gives recommendations for further research. 
Samenvatting

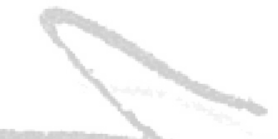


Hoofdstuk 1 geeft inzicht in de ontwikkeling van dit proefschrift. Paratonie is een karakteristieke tonus stoornis in het laatste stadium van dementie. Ondanks het feit dat paratonie al in 1910 is beschreven is er toch weinig wetenschappelijke aandacht voor geweest. Paratonie speelt echter een belangrijke rol in de achteruitgang van de kwaliteit van leven en zorgt voor een exponentiële toename van de zorgzwaarte in de laatste fase van dementie. De prevalentie van paratonie wordt geschat op $10 \%$ in de beginstadia van dementie en loopt op tot liefst $90 \%$ in de laatste fase. $\mathrm{Er}$ is een grote variatie in de beschrijvingen van paratonie te vinden in de internationale literatuur en een beperkt aantal hypothesen over de pathogenese. Passief mobiliseren (PMT) met als doel de spierspanning te reduceren en de mobiliteit te handhaven is één van de meest toegepaste interventies door fysiotherapeuten in de Nederlandse verpleeghuizen. Ondanks dat de verzorging aangeeft dat deze therapie gunstige effecten heeft zijn er bij de fysiotherapeuten twijfels over de effectiviteit. Dit was de belangrijkste reden om het inzicht in paratonie te vergroten. Om dit te realiseren hebben we vier doelen gesteld:

(1) Het realiseren van een valide beschrijving van paratonie

(2) Het ontwikkelen van een instrument om paratonie te kunnen diagnosticeren en te differentiëren van andere spiertonus stoornissen

(3) Het vinden van factoren die de ontwikkeling en de ernst van paratonie kunnen beïnvloeden

(4) Het beantwoorden van de vraag of PMT gunstige effecten heeft op de ernst van paratonie in het laatste stadium van dementie.

Hoofdstuk $\mathbf{2}$ is de beschrijving van de pilot study waarin gekeken is naar het effect van passief mobiliseren (PMT) op ernstige paratonie in vergelijking met goed ondersteunende kussens en een controle groep. Deze gerandomiseerde klinische trial is uitgevoerd in verpleeghuis "De Weerde" in Eindhoven. De deelnemers werden at random ingedeeld in 1 van de 3 groepen; Bij groep 1 werd de interventie PMT drie keer per week toegepast, groep 2 kreeg goed ondersteunende kussens en groep 3 fungeerde als controle groep. In totaal werden negen behandelingen gegeven en de ernst van de paratonie werd bij de deelnemers voor en na elke behandeling met de Modified Ashworth scale geëvalueerd. Alle vier de ledematen werden in vier bewegingsrichtingen gemeten (flexie, extensie, abductie en adductie). Na screening en proxy consent zijn er 15 deelnemers geincludeerd, 5 in elke groep. Goed ondersteunende kussen hadden een gunstig effect voor beide armen na 3 weken en voor de flexie van beide benen na elke behandeling (niet significant). Een trend analyse gaf aan dat PMT een gunstig effect lijkt te hebben na elke behandeling, dit ondersteund de ervaren gunstige effecten door de verzorging. Echter de lange termijn effecten blijven onduidelijk. 
Hoofdstuk 3 beschrijft de Delphi procedure waarmee een internationale consensus definitie tot stand is gekomen. De Delphi procedure is een techniek waarmee anoniem in een aantal fasen een vragenlijst wordt gepresenteerd. Elke fase bouwt voort op de voorafgaande fase. Acht van de zeventien geïdentificeerde en benaderde experts gingen akkoord met deelname. De vragenlijst was verdeeld in 3 categorieën; meest gebruikte beschrijvingen, factoren die de mate van paratonie beïnvloeden en mogelijke elementen die paratonie kunnen onderscheiden van rigiditeit bij $\mathrm{m}$. Parkinson en spasticiteit. $\mathrm{Na} 4$ ronden bereikten de deelnemers consensus over 4 korte beschrijvingen, 4 beïnvloedende factoren en 2 onderscheidende elementen die van belang zijn voor een goede beschrijving van paratonie. Uiteindelijk is dit samengevoegd tot 1 consensus definitie; Paratonie is een vorm van hypertonie met een onvrijwillige variabele weerstand tegen passief bewegen. Met progressie van de dementie kan de uitingsvorm van paratonie veranderen (van actief meebewegen (ook bekend als 'Mitgehen') in het begin van de ziekte naar actief tegenbewegen in de latere stadia). De mate van weerstand is afhankelijk van de snelheid van bewegen (langzaam bewegen geeft weinig weerstand, snel bewegen geeft veel weerstand). De mate van weerstand is afhankelijk van de kracht die door de onderzoeker wordt gebruikt. En de weerstand kan in elke bewegingsrichting voelbaar zijn en er is geen knipmesfenomeen.

In Hoofdstuk 4 wordt de transformatie beschreven van de nieuwe consensus definitie naar een goed toepasbaar diagnostisch instrument. Hiervoor is een 3 fasen cross-sectioneel onderzoek verricht. Het Paratonia Assessment Instrument (PAI) is in de eerste twee fasen ontwikkeld en gevalideerd. In de derde fase is de inter-beoordelaars betrouwbaarheid getoetst alsmede de toepasbaarheid van het instrument. Inter- beoordelaars betrouwbaarheid tussen de twee meters was in de eerste fase Cohen's $\mathrm{k} 0.532$ en verbeterde in de tweede fase naar Cohen's k 0.677 . Twee onafhankelijke meters valideerde deze betrouwbaarheid in de derde fase met Cohen's $k$ tussen 0.625 en 1. Het definitieve diagnostische instrument PAl bestaat uit 5 specifieke criteria die elk een karakteristieke eigenschap van paratonie vertegenwoordigen. De aanwezigheid van paratonie kan vastgesteld worden door het uitvoeren van een eenvoudig bewegingsonderzoek bij een patiënt in zit door middel van de schouders, ellebogen en de heupen in flexie en extensie langzaam en snel te bewegen. Er is sprake van paratonie als alle vijf de volgende criteria aanwezig zijn; 1) Er is een onvrijwillige variabele weerstand tegen passief bewegen. 2) De mate van weerstand is afhankelijk van de snelheid van bewegen (langzaam bewegen, weinig weerstand en snel bewegen, veel weerstand). 3) De weerstand kan in elke richting gevoeld worden. 4) er is geen knipmesfenomeen. 5) de weerstand wordt gevoeld in 2 bewegingsrichtingen in 1 ledemaat of in 2 verschillende ledematen. 
In Hoofdstuk 5 wordt een multi-center longitudinale cohort study met 1 jaar follow-up beschreven waarin de prevalentie, incidentie en de risico factoren voor paratonie bij dementie onderzocht zijn. Voor dit onderzoek werd gezocht naar fitte en mobiele personen met dementia, in stadium 6 of lager op de Global Deterioration Scale van Reisberg. De mensen mochten alleen deelnemen aan het onderzoek als ze ook het informed consent of proxy consent formulier hadden ondertekend. De potentiële deelnemers werden gezocht in psychogeriatrische dagbehandelingen van verpleeghuizen en verzorgingshuizen of speciale psychogeriatrische afdelingen in verzorgingshuizen in de regio's Eindhoven, Helmond en Tilburg.

De Paratonia Assessment Instrument (PAI) om paratonie te kunnen vaststellen was het voornaamste meetinstrument wat bij alle deelnemers werd gebruikt. Daarnaast werd de functionele mobiliteit met de Timed Up and GO (TUG)test gemeten. De kwaliteit van leven met de Qualidem, de ernst van de dementie met de GDS van Reisberg, het cognitief verval met de Mini Mental State Examination (MMSE) en de diagnose van dementie, overige aandoeningen en het medicijn gebruik werd uit het op de afdeling aanwezige medische dossier gehaald en aangevuld met gegevens van de huisarts. De PAI werd elke 3 maanden afgenomen en alle andere variabelen werden bij de start van het onderzoek en op het eind, na 12 maanden, getest.

Bij de start van het onderzoek zijn 204 deelnemers getest, 111 (54\%) vrouwen en 93 (46\%) mannen met een gemiddelde leeftijd van 79,8 jaar (56-97). Bij 71 (34,8\%) werd paratonie vastgesteld. In de loop van het jaar ontwikkelde zich paratonie bij 51 deelnemers. De groep met Vasculaire Dementie had de hoogste Hazard Ratio (3.1) om paratonie te ontwikkelen in 1 jaar en bovendien werd in deze groep één van de hoogste prevalenties gemeten bij de start van het onderzoek (42\%).

Logistische regressie liet zien dat 1 punt lager op de MMSE (OR=.90) en Diabetes Mellitus $(\mathrm{OR}=10.7)$ beide significante factoren zijn voor het ontwikkelen van paratonie (Wald chi square $\mathrm{p}$-waarde <.01). De conclusie uit dit onderzoek was dat DM een significante factor is in de ontwikkeling van paratonie en wellicht ook vasculaire schade.

In Hoofdstuk 6 wordt het studie protocol beschreven om het effect van passief mobiliseren (PMT) op de ernst van paratonie en op de verzorgbaarheid te onderzoeken door middel van een multi-centre gerandomiseerde klinische trial (RCT). Er wordt hierin een RCT voorgesteld met een follow-up van 4 weken waarbij patiënten met matig tot ernstige paratonie kunnen deelnemen. De patiënten worden alleen geincludeerd als er sprake is van proxy consent. Door middel van een computerprogramma vindt er een geblindeerde block-randomisatie plaats (block-size van 4) waarbij de deelnemers worden verdeeld in 2 groepen. Groep 1 krijgt de behandeling PMT en groep 2 krijgt de gewone dagelijkse zorg zonder PMT. In dit hoofdstuk wordt de werkwijze van PMT uitgebreid beschreven. Het onderzoeksprotocol schrijft 
voor dat PMT 3 keer per week, 4 weken lang, door een fysiotherapeut wordt gegeven. De belangrijkste uitkomstmaat is de gemodificeerde Ashworth schaal (MAS) waarmee de ernst van de paratonie in kaart gebracht kan worden. De verbeteringen in verzorgbaarheid wordt in kaart gebracht door middel van de Klinische Globale impressie schaal (CGI) en een voor dit onderzoek gemodificeerde versie van de Patiënt specifieke klachten lijst (PSK, afgekort in het Engels als PSC). Verder wordt de Pain Assessment Checklist for Seniors with Limited Ability to Communicate, Dutch version (PACSLAC-D) ingezet om een afname van de pijn, een mogelijk neven effect van PMT, gedurende de ochtendzorg te observeren. De metingen vinden plaats bij de start van het onderzoek kort voor de eerste behandeling, na twee weken 1 dag na de 6 de behandeling en na 4 weken 1 dag na de 12 de behandeling. Het noodzakelijk aantal deelnemers (sample-size) is berekend aan de hand van de gegevens uit de pilot studie (Hoofdstuk 2) en komt uit op 69 patiënten per groep. Dit hoofdstuk eindigt met een voorstel voor de statistische analyse.

In Hoofdstuk 7 worden de resultaten gepresenteerd van de multi-centre gerandomiseerde klinische trial in 12 Nederlandse verpleeghuizen. In totaal hebben 102 patiënten deelgenomen en zijn de meetgegevens van 101 deelnemers geanalyseerd. De gegevens zijn verzameld tussen april 2007 en april 2009.

$82,2 \%(n=83)$ van de deelnemers was vrouw. De gemiddelde leeftijd was 84 jaar (range 67-98) en de meeste deelnemers bevonden zich in de laatste en ernstigste fase van dementie GDS 7 $(65,3 \%, n=66)$. Het merendeel van de deelnemers had de diagnose ziekte van Alzheimer (AD) $(63 \%, n=64), 18 \%(n=18)$ vasculaire dementie $(\operatorname{VaD}), 11 \%(n=11)$ een combinatie van $A D$ en VaD, $4 \%$ (4) de diagnose Lewy body dementie en in de overige $4 \%(n=4)$ was de diagnose dementie niet nader gespecificeerd.

De meetgegevens van de gemodificeerde Ashworth schaal werd geanalyseerd door middel van mixed effect lineair model op 3 niveaus, met tijd genest in het patiënt niveau dat weer genest was in het instituut niveau. Deze zelfde procedure is gebruikt voor de analyse van de PACSLAC-D gegevens en de PSK data. Bij deze laatste is de data op het eerste niveau volledig cross-classified om rekening te houden met de onderlinge afhankelijkheid van de 3 vragen. In de analyse is verder rekening gehouden met de meetgegevens bij de start van het onderzoek, de verschillende type en stadia van dementie en het natuurlijke tijdseffect. De verschillende verpleeghuizen en type en stadia van dementie zijn als interactie termen in het model verwerkt om te zien of deze factoren een rol speelden op het effect van PMT. Tot slot zijn de gegevens van de CGI door middel van kruis tabellen chi-kwadraat getoetst.

Het resultaat van dit onderzoek liet een trend zien van verergering van de stijfheid bij de deelnemers die PMT hadden gekregen in vergelijking met de controle groep en dus zeker geen vermindering van de spierspanning. Alhoewel dit niet statistisch significant was is deze bevinding wel degelijk klinisch relevant om dat de interventie juist bedoeld is om de 
spierspanning te doen afnemen. Bovendien is er geen indicatie gevonden dat de zorgzwaarte afneemt door PMT. PMT wordt daarom afgeraden als interventie bij ernstige paratonie.

Tot slot in Hoofdstuk 8, de algemene discussie, wordt een overzicht gegeven van de belangrijkste bevindingen uit dit proefschrift en worden de methodologische sterke en zwakke punten besproken van alle onderzoeken. Dit hoofdstuk eindigt met een discussie over de implicaties van de belangrijkste bevindingen voor de dagelijkse praktijk en aanbevelingen voor vervolg onderzoek. 